\title{
Uwarunkowania etnogenetyczne na przykładzie procesu chrystianizacji Bułgarów
}

\author{
Uladzimir Mazgou \\ Chrześcijańska Akademia Teologiczna \\ Warszawa, Polska \\ kirillmefody.volk@mail.ru
}

U. Mazgou, Ethnogenesis Conditions in the Christianity Bulgarian Process, Elpis, 20 2018: 49-55.

\begin{abstract}
The article above as a part of the Author's dissertation, introducing a Lector in the very interesting period of the Bulgarian Christianity progress: the existential beginning of the First Bulgarian Empire. This period characterises Altay nation conscientiousness as a base of the perception of Truth. Those citizens did not have to obey the Christians rules, so their progress of integrity with other Balkan peoples and in consequence of their Christian life dimension could be finished even after the 1018, year of the Empire fail. So we can notice, that one of the most important country in the Orthodox world, constructed on the Altay base started in contraction between two traditions: saint Fathers' from Greece and of the Rome catholic one (contacts with the Pope Nicolas the First).

Streszczenie: Przedstawiony artykuł stanowiący część rozprawy dysertacyjnej porusza szczegółowe, acz bardzo istotne dla prezentacji procesu chrystianizacyjnego Bułgarii zagadnienie: świadomości narodowej jako fundamentu percepcji chrześcijaństwa. Autor wskazuje, iż mieszkańcy Pierwszego Carstwa nie byli Słowianami, sugeruje też, iż proces slawizacji mógł się zakończyć nawet po roku 1018. Przeto początki chrześcijańskiego wymiaru życia jednego z najważniejszych w swojej epoce państw Ortodoksji to de facto proces zderzenia mentalności ałtajskiej z tradycją świętych Cyryla i Metodego oraz kontaktami z papieżem Mikołajem I.
\end{abstract}

Keywords: theology, Orthodox, Church, christianity, Bulgaria, a human being

Słowa kluczowe: teologia, Prawosławie, Cerkiew, chrystianizacja, Bułgaria, człowiek

Temat niniejszego opracowania wydaje się szczególnie emocjonujący. Przekształcenie ludu koczowniczego na lud osiadły, w nauce często traktowane jako fenomen punktyczny, rozgrywający się w ramach niewielkiego odcinka czasowego, jest przecież konglomeratem różnorodnych procesów dziejących się na płaszczyźnie językowej, obyczajowej, cywilizacyjnej... Rezultatem takiego wieloaspektowego procesu bywa nieznaczne, niewiele różniące się od punktu wyjścia, w przypadku Bułgarii jednak realizacja zdobyczy w kontekście procesu slawizacyjnego okazała się stać na najwyższym poziomie. Lud swą proweniencją sięgający Ałtaju przekształcał się w przodujący naród wzbogacający kulturę słowiańską, bardzo poważnie traktujący chrześcijańskie zobowiązania potwierdzając $\mathrm{w}$ ten sposób silną, by nie rzec dominującą pozycję Słowian południowych w tyglu narodowościowym Półwyspu Bałkańskiego.

Skromne rozmiary niniejszego artykułu nie pozwolą na zbyt szczegółową prezentację problemu. Autor postara się jednak o to, by prezentacja ta dotyczyła zagadnień pierwszoplanowych i najbardziej charakterystycznych, to znaczy języka, jako głównego wyznacznika tożsamości narodowej, oraz przedchrześcijańskiego profilu religijnego bułgarskiego narodu jako zasadniczego punktu wyjścia procesu chrystianizacji.

\section{Język bułgarski (?)}

„Cywilizacja kształtowana przez chrześcijaństwo Wschodu i Zachodu staje się wspólnym językiem Europy i fundamentem jedności całego kontynentu, a zwłaszcza wówczas, gdy Europa była domem ludzi wierzących w Chrystusa, czyli w czasach średniowiecza", stwierdza ks. A. W. Niewęgłowski, warszawski teolog i poeta ${ }^{1}$. Rozpatrując nieco szerzej myśl tego cytatu można uznać, że język jest podstawowym wyznacznikiem tożsamości narodowej.

Jak się wydaje, wokół języka bułgarskiego, a zwłaszcza w odniesieniu do pierwszego etapu realizowania bułgarskiej państwowości w dobie średniowiecza, narosło kilka spraw dyskusyjnych, od których pragnę rozpocząć. Za najważniejszą uważam kwestię języka starobułgarskiego, który w opinii większości europejskich lingwistów trwał do wieku VII do XV. Z uwagi na tematykę artykułu, prześledźmy początkowy period jego rozwoju.

W powszechnej świadomości język bułgarski kojarzony jest ze słowiańską rodziną językową. Nie zapominaj-

Ks. W.A. Niewęgłowski, Kulturowe korzenie Europy, [w:] Chrześcijańska Europa, praca zbiorowa pod redakcja naukową ks. prof. S. Urbańskiego, Warszawa 2003, s. 35. 
my jednak, iż proces „słowiańskości bułgarskiej” to wynik działania zewnętrznego, rezultat wpływów egzogennych. Wszak lud przybywający na Bałkany był ludem tureckim, język jego znacznie się różnił od języków nowego otoczenia. Prawdopodobnie był to język wywodzący się z tej samej grupy, do której należy współczesny język czuwaski, który jako jedyny z grupy nadwołżańskiej charakteryzuje się nieprzerwanym continuum historycznym.

Lingwiści bułgarscy także wskazują na to, iż proces slawizacji mógł być długi i niekoniecznie zakończyć się w dobie Pierwszego Carstwa ${ }^{2}$, a wskazywane przez nich tureckie wpływy odnajdywane nawet we współczesnym języku bułgarskim mogą równie dobrze być rezultatem oddziaływania kraju pochodzenia ${ }^{3}$.

Przełomowym czasem $\mathrm{w}$ historii przedchrześcijańskich Bułgarów był wiek V po Chrystusie, kiedy tworzące „formację bułgarską" plemiona koczownicze przebywając na stepach czarnomorskich i na terenie Zakaukazia stykają się ze starą, wywodzącą się jeszcze sprzed naszej ery, kulturą sarmackich Alanów.

Bardzo dobrą charakterystykę tej grupy etnicznej znajdziemy u starożytnego żydowskiego historyka, Józefa Flawiusza, tak opisującego wyprawę Alanów na ziemie Iranu: „Liczne ich hordy uderzyły na nic nie przeczuwających Medów i splądrowały kraj gęsto zaludniony i zasobny we wszelakie rodzaje bydła, a nikt nie odważył się stawić im oporu”. Król Medów „zbiegł ze strachu w niedostępne ustronie, pozostawiając wszystkie swoje posiadłości na pastwę losu"4.

A gdy Alanowie wkroczyli do Armenii Irańskiej, ich władcę porwali na arkan, tak iż omal życia nie stracił, a następnie spustoszyli ziemie, zabierając wiele bogactw5

Był to zatem lud dość typowy dla swojej epoki, oddziałujący też sposobem bycia na okoliczne narody. Ich spotkanie z Protobułgarami na stepach nad Wołgą po podbiciu przez Hunów (koniec IV wieku) pozwala też przodkom Bułgarów zainicjować nowy okres swych dziejów. Oba ludy podejmują wspólną walkę z Ostrogotami, tracąc dwu ważnych swych wodzów. Walka ta jest jednak zauważona w wymiarze międzynarodowym - bizantyjski cesarz Zenon zatrudnia bułgarskie wojsko jako najemników, by

\footnotetext{
2 Zwracano uwagę na istnienie w tym czasie tak zwanej szkoły ochrydzkiej, mającej szeroki zakres oddziaływania kulturowego także na Ruś. Warto jednak zauważyć, iż w szkole promowano teksty staro cerkiewno słowiańskie, nie zaś bułgarskie. Por. Też Mirczew K., Istoriczeska gramatika na bułgarski jezik, 1955, s. 30.

3 Stanowisko naukowe poszczególnych krajów streszcza, acz nie zawsze dokładnie i wiarogodnie, Wikipedia. Na tej podstawie możemy stwierdzić, iż uczeni anglojęzyczni uważają język starocerkiewno słowiański za pierwotny bułgarski system glottyczny na Bałkanach. Był on bowiem norma językową dla całej Słowiańszczyzny Południowej. Lingwiści francuscy w starobułgarskim widzą wpływy trackie, a nawet irańskie, podkreślają też turecką proweniencję pierwotnego języka Bułgarów. Z kolei Rosjanie zwracają uwagę na to, iż w etapie piśmienniczym języka bułgarskiego da się zauważyć niewątpliwy wpływ dzieła Cyryla i Metodego, których uczniów kniaź Borys przyjmuje pod opiekę w roku 885, by chronić ich przed morawskimi prześladowaniami. Dzięki temu gestowi władcy zaistniała działalność wielkiego Klemensa z Ochrydy i jego wspaniałej szkoły.

4 Józef Flawiusz, De bello judaico, liber VII, capitulum VII,4.

5 Por. T. Sulimowski, Sarmaci, Warszawa 1979, s. 123-124.
}

dalej walczyli z Ostrogotami. Jest rok 481, gdy Bułgarzy po raz pierwszy pojawią się w oficjalnych dokumentach.

Zetknięcie $\mathrm{z}$ Hunami oznaczało kontakt $\mathrm{z}$ językiem ałtajskim, który zgodnie z określeniem Omeliana Pridsaka był czymś pośrednim „miedzy językiem tureckim a mongolskim, prawdopodobnie bliższy temu pierwszemu. Język ten wykazuje silne powiązania między starobułgarskim a współczesnym czuwaskim ${ }^{6}$, mimo niewątpliwych wpływów języków okolicznych, między innymi słowiańskich. Można jednak uznać za pewnik, iż bezpośrednimi „ojcami” Bułgarów byli Hunowie, a Protobułgarzy stali się ojcami Czuwaszów ${ }^{7}$, aczkolwiek pozostałości języka huńskiego są dość skąpe, przeto analiza jego pozostałości (zwłaszcza w nazwach własnych) po dziś dzień nie przynosi pozytywnych rezultatów ${ }^{8}$.

Począwszy od wieku VI, nad Morzem Azowskim zostaje założone państwo, określane mianem Wielkiej lub Starej Bułgarii z portem Fanagoria jako stolicą. Państwo to miało przetrwać ponad wiek ${ }^{9}$.

Zważywszy na wcześniejsze ustalenia Omeliana Pritsaka językiem, którym mówiono w tym państwie z pewnością nie był język słowiański, można przyjąć, iż nawet słowiańskie wpływy były tam ograniczone. W najbliższym otoczeniu tego państwa, znajdowały się bowiem ludy, których bardzo interesujący, acz na poły fantastyczny opis spotkamy w Historii Świata pochodzącego z Gazy Zachariasza Scholastyka, biskupa Mityleny na wyspie Lesbos w latach 536-553. Duchowny ten wraz z innymi prowadził na terenie bułgarskiego państwa misje, dzięki którym lud dotąd inaczej wierzący spotyka się po raz pierwszy z chrześcijaństwem. „A miejsce to [Wielka Bułgaria] pogańskie jest i barbarzyńskie, choć spotkasz tam i miasta, i twierdze. Jest tam jeden naród ludzi-psów, a na zachód i na północ od niego żyją amazonki (amazonides), dziewczęta $\mathrm{z}$ jedną piersią. W tym psim narodzie mężczyzn nie uświadczysz, albowiem jeśli się i jaki narodzi, wraz go zabijają. Sąsiaduje z nimi naród herosów, gdzie mężczyźni bardzo wysocy, jednakże broni nosić nie mogą. Prócz tego są tam trzy czarne narody" 10 .

Nawet pobieżna analiza tego opisu nie wskaże na to, by bezpośrednimi sąsiadami Wielkiej Bułgarii byli Słowianie $^{11}$.

Po upadku Wielkiej Bułgarii nastąpiła dalsza wędrówka w stronę Półwyspu Bałkańskiego, Protobułgarzy rozdzielili się, jedna ich część pozostała nad Wołgą, druga

\footnotetext{
6 Omelian Pritsak, The Hunnic Language of the Attila Clan, Harvard Ukrainian Studies, 1982. 6, s. 470.

Por. szerzej w tej materii D. Sinor, The Hun period [w:] Tenże, The Cambridge History of earliy inner Asia, Cambridge 1990, s. 202.

8 Tamże, s. 201.

Zgodnie z przekazem kronikarskim jego oddziaływanie na sąsiadów charakteryzowało się ekspansywnością, a nawet okrucieństwem.

10 Por. Zachariasz Scholastyk, Kronika 1, 158 [wersja internetowa], http://www.vostlit.info/ (1. III. 2016). Swój przydomek zawdzięcza on wykonywanej prawdopodobnie w Konstantynopolu praktyce adwokackiej. Jako biskup Mityleny wziął udział w soborze konstantynopolitańskim I jako zdecydowany przeciwnik monofizytów. Oprócz wspomnianej Historii świata, doprowadzonej do roku 568/569 jest również autorem zachowanego w języku syryjskim Żywota Sewera z Antiochii.

11 Jak się obecnie przyjmuje byli to przedstawiciele grupy ugrofińskiej.
} 
powędrowała dalej, aczkolwiek wspólnotę języka zachowano. Osiedleni nad Wołgą jeszcze bardziej pracowali nad swą ałtajska tożsamością, dając początek współczesnemu ludowi czuwaskiemu, będącemu wypadkową prototypu fińskiego i tureckiego. Poznajmy jakość glottogenezy ich języka, by rozwiązać interesującą nas „kwestię bułgarską”. Sprawa jednakże nie jest prosta.

Pochodzenie języka było jednym $\mathrm{z}$ istotnych zagadnień uczonych radzieckich już w latach pięćdziesiątych minionego stulecia ${ }^{12}$. Długoletnie badania doprowadziły do zaistnienia zasadniczo dwu koncepcji.

Jedną z nich reprezentuje grupa uczonych (miedzy innymi N. I. Jegorow), którzy źródeł języka czuwaskiego szukają w konglomeracie mongolskim, perskim i arabskim, aczkolwiek zasadniczą jego część wywodzą od języka Protobułgarów z okresu Wielkiej Bułgarii. Na podstawie hasła tegoż autora, Glottogieniez czuwaszskij w Czuwaskiej Encyklopedii ${ }^{13}$ możemy jednakże sformułować też inną koncepcję genetyczną: omawiany język to substrat maryjskiego i języków tureckich.

Za głównego rzecznika tureckiego pochodzenia języka czuwaskiego uznać należy B. A. Sieriebriennikowa ${ }^{14}$, który jednak wierny pryncypialności wpływów tureckich, na podstawie materiału leksykalnego nie omieszka wspomnieć też o wpływach innych: sybirskich czy tungusko-mandżurskich. Wskazany autor pisze: „Powszechne oddziaływanie języka tureckiego dało szczególnie znać o sobie na terenie Azji. Przykładem takiego oddziaływania jest badany na nowo przodek współczesnego języka Czuwaszów, którego geograficznego źródła poszukiwać należy prawdopodobnie w okolicach Jeziora Bajkał, na co wskazuje sąsiedzkie oddziaływanie języków mongolskich"15.

Wskazany uczony potwierdza, iż „tureckojęzyczni przodkowie współczesnych Czuwaszów uważani być mogą za pierwsze plemiona przenikające do Europy. Obecność tych plemion w niskim i średnim biegu Wołgi dała podstawę do zaistnienia dwu języków: chazarskiego i czuwaskiego" 16 .

„Istotny związek - kontynuuje wskazany autor - miedzy językiem bułgarskim a czuwaskim zdaje się nie ulegać wątpliwości. Wiele nawet współczesnych słów języka bułgarskiego charakteryzuje się takimi samymi cechami szczególnymi, które spotykamy tylko w języku czuwaskim, nie dają się one znaleźć w innych tureckich językach"17.

\footnotetext{
12 Działo się to w okresie rządów J.W. Stalina, który uchodził za najwybitniejszego językoznawcę, stąd kwestie te traktowano jako priorytetowe. Podobna sytuacja trwała także w późniejszych dziesięcioleciach, stąd jedną z pozostałości po okresie radzieckim jest bardzo starannie przygotowana seria Wielkich Słowników dwujęzycznych (zawsze z odwołaniem do rosyjskiego), obejmujących całokształt języków narodów radzieckich i mniejszości narodowych (np. Bolszoj Słowar' russko-polskij lub Wielki Stownik polsko-rosyjski).

13 Wersja internetowa (1.III.2016)

14 B.A. Sieriebriennikow, Proischożdienije czuwasz po dannym języka [w:] Praca zbiorowa, O proischożdienii czuwaszkogo naroda, Czeboksary 1957, s.41

15 Tamże

16 Tamże, s. 43

17 Tamże, s. 44
}

Reprezentantem nowej myśli lingwistycznej jest rosyjski uczony doby po radzieckiej, A. B. Dybo. Zwracając uwagę na chronologię powstawania języków, za spiritus movens tego procesu uważa on rozpad języka staro tureckiego. Jako jeden z pierwotnych procesów wskazuje on wyodrębnienie się języka czuwaskiego z bułgarskiej grupy językowej. Jednocześnie uczony ten wskazuje na powiązania omawianej grupy z językami Dalekiego Wschodu ${ }^{18}$.

Analizując fenomen języka czuwaskiego jako reprezentanta grupy tureckiej winniśmy wskazać na kilka cech charakterystycznych, wpływających niewątpliwie na sposób opisu świata i na jego recepcję, mając jednocześnie na uwadze, iż podobnie jak to ma miejsce obecnie, i dawniej wyróżniał się on bogactwem fleksyjnym i słowotwórczym, w związku z czym bywał niezrozumiały dla większości reprezentantów omawianej grupy ${ }^{19}$. Jego najważniejszymi cechami są:

- aglutynacyjna harmonia samogłosek. Aglutynacyjność tego języka wyraża się brakiem struktur koniugacyjnych i deklinacyjnych, przekaz informacji tworząc za pomocą „dolepianych” elementów językowych; na bazie jednego, tak utworzonego słowa możliwe się staje przekazanie treści całego zdania. Zasada harmonii porządkuje zależność poszczególnych samogłosek od siebie na podstawie schematu nazywanego ,trójkątem fonetycznym”20;

- „zerowy” podmiot zdaniowy, czyli brak konieczności stawiania rzeczownika lub zaimka dla pełnego przedstawienia sprawcy danej czynności $i^{21}$;

- odnośnie do rzeczownika odnotowuje się też brak rodzajnikó $w^{22}$ i rodzaju gramatycznego ${ }^{23}$;

- uporządkowanie słów w logicznym układzie zdania uzależnione jest od danej grupy tworzącej języki tureckie.

Możemy zatem być pewni, że wchodząc na tereny Półwyspu Bałkańskiego Bułgarzy wnosili z sobą wraz z odmiennym ,genomem lingwistycznym” także odmienną atmosferę i obyczajowość. Język bowiem budował właściwy dla siebie kształt ich świadomości, przy jednoczesnym

\footnotetext{
18 Por. A. B. Dybo, Chronologia tiurskich jazykow i lingwisticzeskije kontakty rannych tiurkow, Moskwa 2004, s. 766.

19 Wskazanie charakterystycznych cech językowych na podstawie The Chuvash language, Wikipedia org. [strona angielska i polska] (1. III. 2016).

20 Graficzne wyobrażenie trójkąta wskazuje odpowiedniość poszczególnych samogłosek (np. a - e, e - i), jak i ich samodzielność, np. samogłoska u, umiejscawiana zwykle na szczycie trójkąta. Oczywiście, ilość samogłosek (podobnie jak ilość głosek) uwarunkowana jest systemem fonetycznym danego języka. W językach tureckich ich ilość przewyższa liczbę głosek białoruskiego czy rosyjskiego, stąd na przykład do zapisu języka czuwaskiego używa się cyrylicy modyfikowanej, wzbogaconej o nowe, acz będące wariantami starych, znaki.

${ }^{21}$ Czyli sytuacja jest całkowicie odmienna, niż w języku angielskim, gdzie brak określonego rzeczownika bądź zaimka przed czasownikiem sprawia całkowity brak jasności co do jego jakości i formy przekazu treściowego. Go to school nie oznacza (Ja) idę do szkoły, lecz Idź do szkoły (tryb rozkazujący). W niektórych językach (na przykład słowiańskich) dysponujemy ograniczoną koniecznością używania jednoznacznego podmiotu. Ja idu w szkołu oznacza to samo, co Idu w szkołu. W językach tureckich stawianie podmiotu dopuszczalne jest tylko w wypadkach wyjątkowych.

22 Jak angielskie the;

23 Występuje, podobnie jak w języku angielskim, wyłącznie „rodzaj naturalny".
} 
stykaniu się z kulturami odmiennymi, wnoszonymi przez Slowian.

Jednakże postawiony przy podtytule znak zapytania można uznać za wyraz powątpiewania, czy w interesującym nas, inicjalnym okresie bałkańskiej państwowości mamy do czynienia z ludem słowiańskim czy jeszcze nie. Trwający (przynajmniej hipotetycznie, acz w nawiązaniu do koncepcji naukowej) period średnio bułgarski chyba jednoznacznie rozwiewa wątpliwości: naród przyjmujący chrzest nie był narodem w pełni słowiańskim, stąd przejawy słowiańskiego wymiaru chrześcijaństwa, określonego choćby misją świętych Cyryla i Metodego, nie musiały mieć tak wielkiego znaczenia, jak dla narodów par excellence słowiańskich.

\section{Czuwaski model mitologiczny a pierwsze próby chrystianizacyjne ${ }^{24}$}

Mitologia czuwaska wydaje się bardzo reprezentatywna dla omawianego problemu. Zważywszy na współczesną aktywność kultury czuwaskiej możemy bez wątpienia przyjąć, iż występujące w tym narodzie wierzenia oddziaływały na cały ,wielko turecki” obszar.

Bardzo dobrze i jednoznacznie omawiane zagadnienie wyjaśnia opublikowana w roku 1908 książka węgierskiego badacza J. Meszaros, „Stare wierzenia Czuwaszów”, który w ogólnym odniesieniu do przedmiotu wskazuje na znaczną powierzchowność tych wierzeń i otwartość ich na wpływy zewnętrzne. Węgierski badacz nie wspomina o żadnej występującej w historii czuwaskiej „reakcji pogańskiej”, jak to się zdarzało choćby w polskiej czy węgierskiej historii. W czasach prowadzenia badań uczony odnosi się do zagadnienia jako czasu minionego, kultywowanego niekiedy sporadycznie zwłaszcza przez starych ludzi.

Niezależnie od zarysowanego stanu rzeczy warto wskazać kilka rysów charakterystycznych tego systemu mitologicznego, który zapewne oddziaływał w momencie procesu chrystianizacyjnego pierwszego państwa bułgarskiego.

Na czele bogów stoi Turan (bądź Tura), co może potwierdzić koncepcję o jego „tureckiej przynależności”. Bóg ten jest jedynym stworzycielem świata i ludzi. Wiemy, kto świat stworzył, lecz nie umiemy powiedzieć, w jaki sposób. Oprócz boga Tura wielkie znaczenie ma bogini Kebe, która modli się w jednej z głównych warstw niebiańskich, a bez jej modlitw nic dobrego nie działoby się na ziemi.

Pogańskie postrzeganie widzi świat wielopoziomowo: składa się on z trzech części, a każda z nich dzieli się jeszcze wewnętrznie. Częściami tymi są: nasz świat, górny świat i zaświaty. Nasz świat jest jednowarstwowy, dwa po-

\footnotetext{
24 Znaczną część materiałów do tego podrozdziału, zwłaszcza w odniesieniu do czuwaskiej mitologii zaczerpnięto ze strony internetowej WWW. gov.cap.ru/hierarchy.
}

zostałe natomiast trójwarstwowe - w rezultacie dysponujemy siedmioma warstwami świata w trójpodziale ${ }^{25}$.

Początek życia na ziemi charakteryzował się jednością języka i wiary, wnet jednak nastąpił rozpad na 77 narodów, 77 języków i 77 różnych wyznań.

Swoistymi „punktami granicznymi” rozmieszczenia tak zarysowanego świata są słońce i księżyc. Interesujące jest spostrzeżenie, iż układ tych warstw zależy od sposobu postępowania ludzkiego. Gdy stają się oni gorsi, granica części górnej podnosi się proporcjonalnie do jakości postępowania. (Dawniej znajdowała się znacznie niżej, lecz ze względu na wzmagające się zło, stale się podnosi).

Ziemia jest kwadratowa, a dzieli się na szereg zamieszkałych przez ludzi krain, z których Czuwaszja znajduje się pośrodku, gdzie jest również, wspierające swym wierzchołkiem niebo, poświęcone kosmiczne drzewo życia. Kwadrat ziemski wspiera się na czterech narożnych kolumnach ze złota, srebra, miedzi i kamienia. Szczyt każdej kolumny ozdobiony został trzema gniazdami, w których kaczki składają swe jaja.

Role strażników bytu ziemskiego pełnią oddziały bohaterów, mający za zadanie ochronę od zła i nieszczęścia. Chociaż Bóg rządzi światem, jednak wsparcie bohaterów (Czuwaszy) jest niezbędne, gdyż grzmoty i błyskawice, rozżarzony metal, są też obrazami gniewu bożego; rodząc się na ziemi mogą spowodować nieszczęście.

Bardzo interesująca wydaje się czuwaska antropologia, rozpatrywana pod kątem nagrody wiecznej. Człowiek traktowany jest czysto dualistycznie: jest albo sprawiedliwym, albo grzesznikiem. W każdym przypadku będzie osądzony: sprawiedliwy po moście tęczy dojdzie do wyższego świata, gdzie przebywają też dusze nienarodzonych dzieci. Co innego grzesznik - ten przejdzie przez wąski i dość niebezpieczny most $\mathrm{w}$ otchłanie piekielne. Stoi tam dziewięć kotłów, pod którymi ogień nieustannie jest podpalany przez sługi diabła.

Już ten pobieżny rys mitologiczny wskazuje, iż wierzenia czuwaskie stanowiły typowy przykład systemu szamańskiego ${ }^{26}$, w którym możemy wyodrębnić trzy elementy: kosmologii (trzypiętrowa organizacja świata, z którą wiąże się pojęcie drzewa kosmicznego, stanowiącego spoiwo wszystkich światów ${ }^{27}$, antropologii i świata duchowego. Można powiedzieć, iż szamanizm, zwłaszcza właściwy ${ }^{28}$ oscyluje pomiędzy tym, co widzialne, a tym, co dla oczu niedostępne.

\footnotetext{
25 Prawdopodobnie, acz nie ma na to bezpośrednich dowodów, symboliczne znaczenie liczby siedem jako odniesienia do doskonałości jest podobne, jak w innych narodach, na przykład semickich.

26 Poprzestańmy na tradycyjnym pojmowaniu szamanizmu: jest to zespół praktyk i wierzeń, gdzie szaman pełni role pośrednika między poszczególnymi, trzema warstwami egzystencjalnymi świata, dzięki swoim zdolnościom ekstatycznym. Może on nawet udać się w zaświaty, do krainy niebiańskich duchów, jeżeli tego będzie wymagało dobro wyznawców czy nawet poszczególnego człowieka (np. chorego). Szamani bardzo często pełnią rolę nauczycieli, przepowiadają przyszłość, uzdrawiają...

27 Drzewo kosmiczne zakorzenione jest w płasko pojmowanej ziemi, by swym wierzchołkiem dosięgnąć nieba.

28 Czyli obecny na terenach syberyjskich
} 
W panteonie czuwaskim występuje około dwustu bóstw, zamieszkujących wszystkie części stworzonego świata, jednakże istnieją religioznawcy skłaniający się do uznania tego systemu religijnego za quasi monoteistyczny, z uwagi na podporządkowanie całego panteonu jednemu Turze czy wręcz wskazywanie na niższą ,jakość” innych prócz Tury bogów panteonu. W. Machnicki twierdzi nawet, iż bogowie ci mieli jedynie znaczenie funkcjonalne. Możemy więc skonstatować sytuację podobną do judaistycznego i chrześcijańskiego obrazu świata: Bóg i Jego Aniołowie...

Obrzędowość czuwaska uwzględnia tradycyjne elementy wynikające z naturalnego rytmu przyrody, a zwłaszcza cykliczności przebiegu rocznego i układu pór roku. Na plan pierwszy tej obrzędowości wysuwają się obchody związane z porą wiosenną. Przejście surowej zimy w kolorowa wiosnę ${ }^{29}$ to okazja do wróżb i snucia planów lub młodzieńczych marzeń.

Za istotną sprawę uważano rozpoczęcie cyklu siewu -orki, wyrażające się „błogosławieństwem” pługa przez szamana czy powszechnym dla całego obszaru tureckiego „święta pługa”. Jak się wydaje, to święto sprowadzało się niekiedy do zaślubin Matki-Ziemi z pługiem, co niewątpliwie miało zapewnić odpowiedni urodzaj i ochronę przed klęskami żywiołowymi, nierozerwalnie związanymi z pracami na roli.

Ceremonialna strona tego wiosennego święta była raczej skromne, sprowadzając się do spożywania prostych dań, jakimi były placki, naleśniki lub jaja na twardo. Część $\mathrm{z}$ tych produktów składano w ofierze Matce-Ziemi, kładąc na przykład jaja między bruzdy pola lub spalając kawałki jedzenia w specjalnie przygotowanym ognisku.

Bardziej uroczyście czczono zakończenie żniw. Składano wówczas ofiary nie tylko z produktów stałych, lecz i płynnych, na przykład piwa (sic).

Niewątpliwie, zasadniczy wymiar tej obrzędowości zawierał się w magii, podobnie jak i czuwaskie modlitwy. Wierzono, iż same słowa maja siłę sprawczą, że to one „uruchamiają” moc poszczególnych bóstw odnośnie do spraw istotnych dla życia i bardzo elementarnie pojmowanej pomyślności.

Tę pomyślność mieli też zapewnić przodkowie, kult których ma charakter magiczny i nie wiąże się z konkretnym obrazem życia pozagrobowego, lecz wyrasta z centralnej pozycji rodziny (klanu) w życiu codziennym Czuwaszów.

Zarysowany powyżej czuwaski obraz ceremonialno-mitologiczny w znacznej mierze bazuje na wzorcach przejętych z ogólno tureckiego modelu (ludów Mari, Ujgurów i innych plemion środkowego Powołża). Jednocześnie pewne założenia mitologiczno-obyczajowe wydają się zbieżne z „modelowymi ujęciami” chrześcijańskimi. Wskazano już na Boga i Aniołów (element monoteistyczny), ważny jest też fenomen ofiarniczy, aczkolwiek skierowany jakby w zwrocie przeciwnym - ku Matce-Ziemi, nie ku Bogu. Także święta judaistyczne i chrześcijańskie wy-

\footnotetext{
29 Nie zapominajmy o klimacie kontynentalnym na terenie Czuwaszji.
}

rastają z rytmu naturalnego. Co prawda, siedzibą bogów nie jest żadna wyniosłość Parnasu czy niebios, lecz podobna do wiary chrześcijańskiej wydaje się postawa zaufania względem nich. Nie wydaje się zatem rzeczą dziwną, iż już w okresie Wielkiej Bułgarii podejmowano próby poznawania chrześcijaństwa.

Znaczną rolę w tym procesie odgrywał wspomniany już biskup Mityleny, Zachariasz Scholastyk z Gazy. Oto obraz zaczerpnięty z jego Historii świata ${ }^{30}$ :

„Ongi biskupowi ziemi Aran o imieniu Kardost objawił się anioł, nakazujący, by wraz z trzema kapłanami udał się w dolinę. Kardost (po grecku Teokletos - miły Bogu) zgodnie z Bożym poleceniem wszedł pomiędzy pogańskie narody. Polecił ich w modlitwie Bogu, a wspierany przez Najwyższego chrzcił nawet martwe dzieci. Po czym zostawił tamtejszy mieszkańcom kapłanów, by zwiastowali tajemnice chrześcijańskie i chrzcili wszystkich przez pokropienie. Kapłani zaś pomiędzy tymi narodami mieli znaleźć wszystko, co niezbędne dla dalszej budowy Królestwa, mimo iż mieli do czynienia zrazu z poganami.

Dla zapewnienia bezpieczeństwa, ewangelizującym kapłanom towarzyszyło czterech przedstawicieli miejscowej ludności, ,a w ziemi, gdzie tak trudno znaleźć schronienie bezpieczne, znaleźli siedmiu [pogańskich?] kapłanów"31, którzy co wieczór dzielili się z nimi siedmioma chlebami i dzbanem wody, prowadząc ich nie pomiędzy siedziby ludzkie, lecz w góry. Tam mieszkali Hunowie, z których wielu ochrzcili o pouczyli o Prawdzie używając ich własnego języka.

Tak się rozpoczęła bułgarska droga ku chrześcijaństwu, będącego z natury swojej fenomenem nie tatarskiej proweniencji. Następuje zatem proces przemian mentalnych, obyczajowych przy jednoczesnym zachowaniu niemożliwej do uniknięcia mentalności „ałtajskiej”. Rodzi się w ten sposób konglomerat owocujący, przynajmniej na początku, wyjątkowo obficie sukcesami.

Marceli Kosman tak się odnosi do tego procesu: „Przemiany światopoglądowe całych społeczeństw to jedno z podstawowych ogniw w historii kultury, a tym samym przedmiot żywych zainteresowań badaczy. Często jednak wymykały się one spod obiektywnych ocen, często także były przedstawiane jednostronnie czy nawet w krzywym zwierciadle /.../ Toteż wokół spraw wiary powstawały mity i legendy, co wypaczało rzeczywistość, a z biegiem czasu utrudniało poważnie naukową rekonstrukcję zjawisk"32.

Nie inaczej było też w omawianym przypadku, aczkolwiek wskazane przemiany stawały się nie tylko ubogaceniem duchowym, lecz wykazywały też związek z wewnętrznymi i zewnętrznymi procesami mentalnymi.

Jak się wydaje, najważniejszą dla właściwego rozumienia „bułgarskiego fenomenu chrześcijaństwa” kwestią jest autonomiczność dwu bardzo podobnych do siebie, by

\footnotetext{
30 Historia świata I, 158, wersja internetowa http://www.vostlift.info (data dostępu 1. III. 2016).

31 Tamże

32 M. Kosman, Od chrztu do chrystianizacji. Polska, Ruś, Litwa, Warszawa 1992, s. 5 [Wprowadzenie].
} 
nie rzec integralnie związanych z sobą fenomenów: aktu chrztu i procesu chrystianizacji. Powyższy cytat ujawnia jednak ich różnorodność, która każe postrzegać akt chrztu jako dobrowolną decyzję ustalenia relacji jednostki z Bogiem, podczas gdy chrystianizacja jest procesem, konsekwencją aktu chrzcielnego, założonego niejako a priori, uznanego tym samym za istotny dla rozwoju także cywilizacyjnego i kulturowego (a więc już nie sensu stricto religijnego) danego obszaru terytorialnego element. Taka sytuacja ewokuje zaś swoistą trudność badawczą, nie pozwalając wcielić aktu przyjęcia chrztu do procesu chrystianizacyjnego. W ten sposób zostaje zanegowany prosty schemat:

Chrzest władcy $=$ chrystianizacja całego podległego społeczeństwa.

Tak zarysowana sytuacja metodologiczna istotna jest w prezentacji historycznej. Królewski akt otwartości na chrześcijaństwo nie oznacza przygotowania całej społeczności do tego aktu. Zdarza się niekiedy, iż chrystianizacja rozpoczyna się aktem decyzyjnym władcy, obejmując ludzi nieświadomych dziejącego się ,ponad ich głowami” procesu. Często pozostaje ona zespolona ze swym dotychczasowym pogańskim dorobkiem (będącym wszak proprium danego społeczeństwa) i uwzględnienia, przynajmniej w elementarnym zakresie, również przejawów kultury pozostającej na obrzeżach chrześcijańskich wpływów ${ }^{33}$. Rozwojowi tego procesu towarzyszy szereg uwarunkowań zarówno natury historycznej, jak i geograficznej, jakości środowiska charakterystycznego dla danej społeczności poddawanej chrystianizacji itp ${ }^{34}$.

Wskazane powyżej przeciwstawienie jest tylko umocnieniem mentalnego pojmowania sakramentu chrztu jako rzeczywistości aksjologicznie wyższej, niż proces chrystianizacyjny. Innymi słowy: recepcja chrztu stanowi w swej istocie tajemnice jednostki, proces chrystianizacyjny podlega opisowi. W opisie tego pełnego dynamizmu procesu wyróżnić możemy :

- elementy właściwe dla danej społeczności, acz proweniencji przedchrześcijańskiej,

- elementy aksjologii i poglądów par excellence chrześcijańskich,

- elementy kultury i cywilizacji wynikające z chrześcijaństwa pośrednio ${ }^{35}$.

Wskazana triada jest czynnikiem istotnym każdego przejawu chrystianizacyjnego, niezależnie od terenu, na którym się dokonuje.

Czynnikiem niezmiernie ważnym jest też stan świadomości wyznawców chrześcijaństwa ukształtowanej, jak w omawianym przypadku, przez elementy obce kulturowo. Mimo formalnego zbliżenia „modeli religijnych”

\footnotetext{
33 Tamże, s. 6-7.

34 Tak zarysowana sytuacja niejako $\mathrm{z}$ natury rzeczy prowadzi do pogańskich reakcji.

35 Rzecz okaże się bardziej złożona w przypadku głębokiego zakorzenienia w cywilizację pogańską, będącą nie tylko proprium danego narodu, lecz także narzędziem jego polityki czy kontaktów z innymi. Najdoskonalszym przykładem może być „,chrystianizacja” Narodu Wybranego przez Jezusa Chrystusa...
}

wskazanych w mitologii czuwaskiej, zakres semantycznego ich pojmowania odmienny jest dla szamanizmu i dla Prawosławia. Każdy zatem proces chrystianizacyjny musi liczyć się z „sytuacją zastaną", czyli punktem wyjścia i czynnikami zbliżającymi do „sytuacji chrześcijańskiej”, w szczegółach pojmowanych zależnie od uwarunkowań konfesyjnych. Dzięki temu aspekt mentalny wskazanego procesu wydaje się priorytetowy, gdyż on w bezpośredni sposób kształtuje pożądane zachowania w obrębie danego systemu wyznaniowego.

Warto tedy zapytać się raz jeszcze o jakość i formę fenomenu chrześcijaństwa. Niech pomocne się stanie sformułowanie tej kwestii w dziewiętnastowiecznej Encyklopedii Nowodworskiego ${ }^{36}$, gdzie znajdziemy jeszcze inny aspekt ujęcia omawianego problemu.

Chrystianizm $^{37}$, zdaniem anonimowego autora odnośnego hasła, to „całe dzieło Chrystusa od wieków przez Boga postanowione, $\mathrm{w}$ [sic] właściwym czasie $\mathrm{w}$ świat wprowadzone i pod opatrznościowym kierunkiem rozwijające swą działalność dla szczęścia ludów i jednostek. [Działalność ta jednak] rozwija się wśród ustawicznej walki z zasadami wypływającymi z poganizmu, [sic] który znowu sam jest wytworem grzechu"38.

Mimo obecności grzechu w procesie chrystianizacyjnym, autor wskazanego hasła koncentruje się na pozytywnym jego aspekcie, co uzasadnia określoną jakością zwiastowanych treści. Oto najważniejsze tej szczególnej jakości przykłady ${ }^{39}$ :

- prawda chrystianizacji pochodzi z pozytywnie pojmowanego Objawienia Bożego;

- treścią przekazu chrystianizacyjnego jest Alfa i Omega, Chrystus;

- jest On punktem odniesienia do dziejów, co sprawia, iż chrześcijaństwo w szerokim tego słowa znaczeniu łączy się de facto z początkiem zaistnienia świata

- On też jako najdoskonalszy Pośrednik między Bogiem a człowiekiem zapewnia Bożemu dziełu chrystianizmu wartość soteriologiczną, a także niezwyciężoną trwałość na ziemi.

Możemy zauważyć, iż wskazany antropocentryzm soteriologiczny jest prawidłowo, bo chrystocentrycznie ukierunkowany. Takie zaś ujęcie omawianej kwestii wpływa też na jakość jej prezentacji w aspekcie historii eklezjalnej $^{40}$.

\footnotetext{
36 Por. M., Chrystianizm,[w:] Encyklopedia Kościelna księdza biskupa Nowodworskiego, t. III, Warszawa 1874, s. 336-339.

37 W opracowaniach teologicznych XIX stulecia nie znano, lub przynajmniej nie preferowano określenia chrystianizacja, zastępując je pojęciem chrystianizmu.

38 Tamże, s. 336.

39 Dość szerokie omówienie uzasadnienia „militarystycznego” stanowi dalszą treść omawianego artykułu encyklopedycznego (s. 336-338).

40 Bardzo charakterystyczny cytat Guy Bedouelle'a OP: „Historia umysłowości uczy historyka Kościoła czegoś istotnego, co uchodziło dotąd jego uwagi /.../ Doprowadza czasem do relatywizacji jednostkowego losu, a być może nawet do granicy wolnego wyboru człowieka na skutek wszystkich determinizmów, jakie ona odkrywa." Nie jest to bowiem historią kwantytatywną. (Kościół w dziejach, przekł. Aldona Fabiś, Poznań 1994, s. 39).
} 


\section{Zakończenie}

„Ideały i marzenia antycznego świata pogańskiego zostały zrealizowane w Jezusie, Który zobowiązywał wszystkich swoich wyznawców do codziennego prakty- kowania prawdy i piękna. I dlatego chrześcijaństwo jest jakby zwieńczeniem tęsknot, oczekiwań i przeczuć złotego wieku antyku"41.

${ }_{41}$ Ks. W. Niewęgłowski, art. cyt., s. 32.

\section{Bibliografia}

Zachariasz Scholastyk, Kronika [wersja internetowa], http:// www.vostlit.info/ (1. III. 2016).

Bedouelle G. OP, Kościót w dziejach, przekł. Aldona Fabiś, Poznań 1994;

Dybo A. B., Chronologia tiurskich jazykow i lingwisticzeskije kontakty rannych tiurkow, Moskwa 2004;

Kosman M., Od chrztu do chrystianizacji. Polska, Ruś, Litwa, Warszawa 1992;

Mirczew K., Istoriczeska gramatika na bułgarski jezik, 1955;

Pritsak O., The Hunnic Language of the Attila Clan, Harvard Ukrainian Studies, 1982;
Sieriebriennikow B. A., Proischożdienije czuwasz po dannym języka [w:] Praca zbiorowa, O proischożdienii czuwaszkogo naroda, Czeboksary 1957;

Sinor D., The Hun period [w:] Tenże, The Cambridge History of earliy inner Asia, Cambridge 1990;

Sulimowski T, Sarmaci, Warszawa 1979;

M., Chrystianizm,[w:] Encyklopedia Kościelna księdza biskupa Nowodworskiego, t. III, Warszawa 1874, s. 336-339.

Niewęgłowski W. A. ks., Kulturowe korzenie Europy, [w:] Chrześcijańska Europa, praca zbiorowa pod redakcja naukową ks. prof. S. Urbańskiego, Warszawa 2003;

Rozmiar artykułu: 0,85 arkusza wydawniczego 


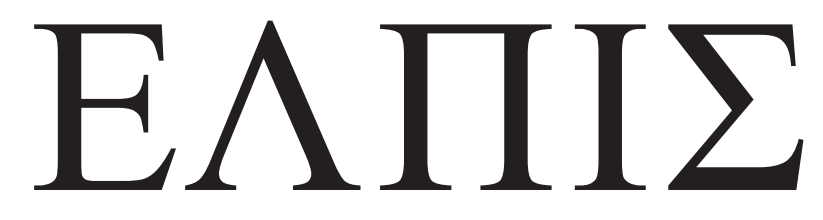

CZASOPISMO TEOLOGICZNE KATEDRY TEOLOGII PRAWOSŁAWNEJ UNIWERSYTETU W BIAŁYMSTOKU

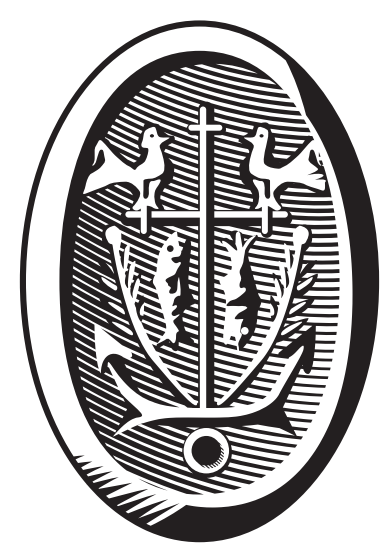

ADRES REDAKCJI

ul. Ludwika Zamenhofa 15, 15-435 Białystok, Polska tel. 85 745-77-80, e-mail: elpis@uwb.edu.pl www.elpis.uwb.edu.pl 